\title{
Night-time radical chemistry during the NAMBLEX campaign
}

\author{
R. Sommariva ${ }^{1, *}$, M. J. Pilling ${ }^{1}$, W. J. Bloss ${ }^{1}$, D. E. Heard ${ }^{1}$, J. D. Lee ${ }^{1, * *}$, Z. L. Fleming ${ }^{2}$, P. S. Monks ${ }^{2}$, \\ J. M. C. Plane ${ }^{3, * * *}$, A. Saiz-Lopez ${ }^{3, * * * *}$, S. M. Ball ${ }^{4, * * * *}$, M. Bitter ${ }^{4}$, R. L. Jones ${ }^{4}$, N. Brough ${ }^{3}$, S. A. Penkett ${ }^{3}$, \\ J. R. Hopkins ${ }^{5}$, A. C. Lewis ${ }^{5}$, and K. A. Read ${ }^{1}$ \\ ${ }^{1}$ School of Chemistry, University of Leeds, Leeds, UK \\ ${ }^{2}$ Department of Chemistry, University of Leicester, Leicester, UK \\ ${ }^{3}$ School of Environmental Sciences, University of East Anglia, Norwich, UK \\ ${ }^{4}$ University Chemical Laboratory, University of Cambridge, Cambridge, UK \\ ${ }^{5}$ Department of Chemistry, University of York, York, UK \\ *now at: Earth System Research Laboratory, National Oceanic and Atmospheric Administration, Boulder, CO, USA \\ ** now at: Department of Chemistry, University of York, York, UK \\ *** now at: School of Chemistry, University of Leeds, Leeds, UK \\ *****now at: NASA Jet Propulsion Laboratory, California Institute of Technology, Pasadena, CA, USA \\ ****** now at: Department of Chemistry, University of Leicester, Leicester, UK
}

Received: 8 May 2006 - Published in Atmos. Chem. Phys. Discuss.: 9 August 2006

Revised: 24 January 2007 - Accepted: 1 February 2007 - Published: 7 February 2007

\begin{abstract}
Night-time chemistry in the Marine Boundary Layer has been modelled using a number of observationally constrained zero-dimensional box-models. The models were based upon the Master Chemical Mechanism (MCM) and the measurements were taken during the North Atlantic Marine Boundary Layer Experiment (NAMBLEX) campaign at Mace Head, Ireland in July-September 2002.

The model could reproduce, within the combined uncertainties, the measured concentration of $\mathrm{HO}_{2}$ (within 30$40 \%$ ) during the night 31 August-1 September and of $\mathrm{HO}_{2}+\mathrm{RO}_{2}$ (within 15-30\%) during several nights of the campaign. The model always overestimated the $\mathrm{NO}_{3}$ measurements made by Differential Optical Absorption Spectroscopy (DOAS) by up to an order of magnitude or more, but agreed with the $\mathrm{NO}_{3}$ Cavity Ring-Down Spectroscopy (CRDS) measurements to within 30-50\%. The most likely explanation of the discrepancy between the two instruments and the model is the reaction of the nitrate radical with inhomogeneously distributed NO, which was measured at concentrations of up to $10 \mathrm{ppt}$, even though this is not enough to fully explain the difference between the DOAS measurements and the model.

A rate of production and destruction analysis showed that radicals were generated during the night mainly by the re-
\end{abstract}

Correspondence to: M. J. Pilling

(m.j.pilling@leeds.ac.uk) action of ozone with light alkenes. The cycling between $\mathrm{HO}_{2} / \mathrm{RO}_{2}$ and $\mathrm{OH}$ was maintained during the night by the low concentrations of $\mathrm{NO}$ and the overall radical concentration was limited by slow loss of peroxy radicals to form peroxides. A strong peak in $\left[\mathrm{NO}_{2}\right]$ during the night 31 August-1 September allowed an insight into the radical fluxes and the connections between the $\mathrm{HO}_{\mathrm{x}}$ and the $\mathrm{NO}_{3}$ cycles.

\section{Introduction}

Radical chemistry during the night is controlled by the reactivity of ozone and of the nitrate radical. $\mathrm{NO}_{3}$ is formed by the reaction of ozone and nitrogen dioxide (Reaction R1), but is present in significant concentrations only during the night, since it is quickly photolyzed by sunlight yielding either $\mathrm{NO}_{2}$ or NO.

$\mathrm{NO}_{2}+\mathrm{O}_{3} \rightarrow \mathrm{NO}_{3}+\mathrm{O}_{2}$

$\mathrm{NO}_{3}$ reacts with $\mathrm{NO}_{2}$ to form $\mathrm{N}_{2} \mathrm{O}_{5}$, which thermally decomposes giving back $\mathrm{NO}_{2}$ and $\mathrm{NO}_{3}$ (Eq. R2). In the nighttime boundary layer $\mathrm{NO}_{3}$ and $\mathrm{N}_{2} \mathrm{O}_{5}$ quickly reach an equilibrium, unless the concentration of $\mathrm{NO}_{2}$ is very low (Allan et al., 2000). $\mathrm{N}_{2} \mathrm{O}_{5}$ therefore acts as an important reservoir of oxidized nitrogen, directly or through the production of

Published by Copernicus GmbH on behalf of the European Geosciences Union. 
$\mathrm{HNO}_{3}$ via the reaction with water (Reactions R3-R4) (Atkinson et al., 2003). $\mathrm{N}_{2} \mathrm{O}_{5}$ and $\mathrm{NO}_{3}$ are also uptaken on aerosol.

$\mathrm{NO}_{3}+\mathrm{NO}_{2}+\mathrm{M} \rightleftharpoons \mathrm{N}_{2} \mathrm{O}_{5}+\mathrm{M}$

$\mathrm{N}_{2} \mathrm{O}_{5}+\mathrm{H}_{2} \mathrm{O} \rightarrow 2 \mathrm{HNO}_{3}$

$\mathrm{N}_{2} \mathrm{O}_{5}+2 \mathrm{H}_{2} \mathrm{O} \rightarrow 2 \mathrm{HNO}_{3}+\mathrm{H}_{2} \mathrm{O}$

$\mathrm{NO}_{3}$ reacts with alkenes and some aromatics (Atkinson and Arey, 2003). The reaction proceeds either by $\mathrm{H}$-abstraction or by addition to the double-bond producing peroxy and nitro-peroxy radicals which then react with $\mathrm{NO}, \mathrm{HO}_{2}$ or other peroxy radicals. Reaction with NO leads to the formation of $\mathrm{HO}_{2}$ and, via the reaction of $\mathrm{HO}_{2}$ with $\mathrm{NO}$ and/or $\mathrm{O}_{3}$, to the formation of $\mathrm{OH}$. In this way the nitrate radical acts as a source of $\mathrm{HO}_{\mathrm{x}}$ during the night, when ozone and formaldehyde photolysis, the main sources of $\mathrm{HO}_{\mathrm{x}}$ radicals during the day, are absent.

Another significant source of $\mathrm{HO}_{\mathrm{x}}$ during the night is the decomposition of Criegee intermediates from the reaction of ozone with alkenes (Atkinson and Arey, 2003). The relative importance of $\mathrm{NO}_{3}$ and $\mathrm{O}_{3}$ as $\mathrm{HO}_{\mathrm{x}}$ sources during the night depends on $\mathrm{NO}_{\mathrm{x}}$ and hydrocarbon concentrations.

Many studies on $\mathrm{NO}_{3}$ chemistry have been reported, e.g. Allan et al. (1999, 2000); Brown et al. (2003, 2004); Vrekoussis et al. (2004), but comparatively few have been published on $\mathrm{HO}_{\mathrm{x}}$ night-time chemistry, especially in the marine boundary layer. $\mathrm{HO}_{2}$ was measured at night at concentrations of up to $7.6 \times 10^{7}$ molecule $\mathrm{cm}^{-3}$ at Oki Island (Kanaya et al., 1999), $1.4 \times 10^{8}$ molecule $\mathrm{cm}^{-3}$ at Okinawa (Kanaya et al., 2001) and $1.1 \times 10^{8}$ molecule $\mathrm{cm}^{-3}$ at Rishiri Island (Kanaya et al., 2002). In all three campaigns the radical source was attributed to the reactions of alkenes and monoterpenes with $\mathrm{O}_{3}$ with little or no contribution by $\mathrm{NO}_{3}$ chemistry. Carslaw et al. (1997) found a positive correlation between $\mathrm{NO}_{3}$ and $\mathrm{HO}_{2}+\mathrm{RO}_{2}$ during spring and autumn at Weybourne on the North Sea, evidence of production of peroxy radicals from reactions of the nitrate radical. No $\mathrm{OH}$ and $\mathrm{HO}_{2}$ measurements were made during that campaign. Salisbury et al. (2001) reported a study of nocturnal peroxy radicals at Mace Head under comparatively clean conditions during the EASE97 campaign. $\mathrm{HO}_{2}$ was measured on two nights at concentrations of up to $5.1 \times 10^{7}$ molecule $\mathrm{cm}^{-3}$. Their study showed that ozone-initiated oxidation routes of alkenes outweighed those of $\mathrm{NO}_{3}$, except when the air was coming from the west and south-west sector. An analysis of peroxy radicals during the night at Cape Grim was also reported by Monks et al. (1996).

This paper discusses night-time modelling and measurements of radicals $\left(\mathrm{OH}, \mathrm{HO}_{2}\right.$, organic peroxy radicals and $\mathrm{NO}_{3}$ ) at Mace Head, Ireland, during the North Atlantic Marine Boundary Layer Experiment (NAMBLEX) (Heard et al., 2006). The campaign took place during the summer of 2002 (July-September) and involved ten British universities
(Aberystwyth, Bristol, Birmingham, Cambridge, East Anglia, Edinburgh, Leeds, Leicester, UMIST, York) and the National University of Ireland, Galway. A complete overview of the campaign is in Heard et al. (2006). Description and analysis of the radical measurements of $\mathrm{HO}_{\mathrm{x}}$ and $\mathrm{NO}_{3}$ can be found in Smith et al. (2006) and Saiz-Lopez et al. (2006), respectively. Another paper by Bitter et al. $(2007)^{1}$ will discuss the $\mathrm{NO}_{3}$ and $\mathrm{N}_{2} \mathrm{O}_{5}$ measurements and try to resolve with a model the differences between the two instruments used during the campaign. A complementary paper by Fleming et al. (2006) used the same model results of this work to compare with the measurements of total peroxy radicals during the day and during the night. This paper focuses on the model-measurements comparisons of $\mathrm{HO}_{2}, \mathrm{HO}_{2}+\mathrm{RO}_{2}, \mathrm{NO}_{3}$ and $\mathrm{N}_{2} \mathrm{O}_{5}$ during the night and uses the model, based on an explicit chemical mechanism, to study the connections between $\mathrm{HO}_{\mathrm{x}}$ and the $\mathrm{NO}_{3} / \mathrm{N}_{2} \mathrm{O}_{5}$ system. A companion paper (Sommariva et al., 2006) describes $\mathrm{OH}$ and $\mathrm{HO}_{2}$ day-time chemistry.

Section 2 of the paper briefly describes the models and the measurements used in this work. Sections 3 and 4 discuss the model-measurements comparisons of $\mathrm{OH}, \mathrm{HO}_{2}, \mathrm{HO}_{2}+\mathrm{RO}_{2}$ and of $\mathrm{NO}_{3}, \mathrm{NO}_{3}+\mathrm{N}_{2} \mathrm{O}_{5}$, respectively. Section 5 contains a detailed rate of production and destruction analysis and Sect. 6 an analysis of one particular night of NAMBLEX (31 August-1 September). Finally, Sect. 7 contains the summary and the main conclusions of this work.

\section{Models and measurements}

The models used in this work are described in detail in Sommariva et al. (2006). They were built following the guidelines detailed in Carslaw et al. (1999) and in Sommariva et al. (2004) and using version 3.1 of the Master Chemical Mechanism (MCM, http://mcm.leeds.ac.uk/).

Four base models, with different degrees of chemical complexity, were used to study the impact of hydrocarbons, oxygenates and peroxides on the calculated concentrations of radicals. All the models were constrained to $15 \mathrm{~min}$ averages of measured concentrations of $\mathrm{CO}, \mathrm{CH}_{4}, \mathrm{H}_{2}, \mathrm{O}_{3}, \mathrm{NO}, \mathrm{NO}_{2}$, $\mathrm{HCHO}$, selected NMHCs, $\mathrm{H}_{2} \mathrm{O}$ and to measured temperature and photolysis rates $\left(\mathrm{j}\left(\mathrm{O}^{1} \mathrm{D}\right), \mathrm{j}\left(\mathrm{NO}_{2}\right), \mathrm{j}(\mathrm{HONO})\right.$, both channels of $\left.\mathrm{j}(\mathrm{HCHO}), \mathrm{j}\left(\mathrm{CH}_{3} \mathrm{COCH}_{3}\right), \mathrm{j}\left(\mathrm{CH}_{3} \mathrm{CHO}\right)\right)$. The constraints of the different models used in this work are shown in Table 1.

The time resolution of the NMHCs measurements was 40 min (Lewis et al., 2005). The data were linearly interpolated to $15 \mathrm{~min}$. The measured species were: ethane, propane, i-butane, n-butane, i-pentane, n-pentane, n-hexane,

\footnotetext{
${ }^{1}$ Bitter, M., Ball, S. M., Povey, I. M., Jones, R. L., Saiz-Lopez, A., and Plane, J. M. C.: Measurements of $\mathrm{NO}_{3}, \mathrm{~N}_{2} \mathrm{O}_{5}$, OIO, $\mathrm{I}_{2}$, water vapour and aerosol optical depth by broadband cavity ringdown spectroscopy during the NAMBLEX campaign, in preparation, 2007.
} 
Table 1. Models used in this work.

\begin{tabular}{|c|c|}
\hline Base Models & Constraints \\
\hline "clean" & $\begin{array}{l}\mathrm{H}_{2}, \mathrm{O}_{3}, \mathrm{NO}, \mathrm{NO}_{2}, \mathrm{HCHO} \text { and } \mathrm{H}_{2} \mathrm{O} \text {, temperature, photolysis } \\
\text { rates. } \mathrm{CO}, \mathrm{CH}_{4}\end{array}$ \\
\hline "full" & as "clean" + 22 hydrocarbons, DMS, $\mathrm{CHCl}_{3}$ \\
\hline "fulloxy" & as "full" +3 oxygenates \\
\hline “fulloxyper" & as "fulloxy" +2 peroxides \\
\hline Test Models & Constraints \\
\hline "fulloxy-n2o5" & as "fulloxy" with $\gamma \mathrm{N}_{2} \mathrm{O}_{5}=0.016$ \\
\hline "fulloxy-no" & as "fulloxy" with $[\mathrm{NO}]=0$ \\
\hline "fulloxy-dms" & as "fulloxy" with [DMS] $=0$ \\
\hline "fulloxy-dms-no" & as "fulloxy" with $[\mathrm{NO}]$ and $[\mathrm{DMS}]=0$ \\
\hline
\end{tabular}

$\mathrm{n}$-heptane, ethene, propene, acetylene, trans-2-butene, but1-ene, i-butene, cis-2-butene, 1,3-butadiene, isoprene, benzene, toluene, ethylbenzene, m-xylene $+p$-xylene, o-xylene plus three oxygenates (acetaldehyde, methanol, acetone) and two peroxides $\left(\mathrm{H}_{2} \mathrm{O}_{2}\right.$ and $\left.\mathrm{CH}_{3} \mathrm{OOH}\right)$ (Lewis et al., 2005). $\mathrm{SO}_{2}$ was not measured and was set to a constant value of 55 ppt (Berresheim et al., 2002).

No peroxides measurements were available after $30 \mathrm{Au}-$ gust. Even before 30 August, their concentrations, and in particular $\left[\mathrm{CH}_{3} \mathrm{OOH}\right]$, were often below or close to the detection limit (0.02 ppb, Morgan and Jackson, 2002). HCHO was measured with two techniques (Still et al., 2006). The University of East Anglia (UEA) measurements were used to constrain the model, because they were made closer to the radical measurements than the Leeds measurements. HCHO data were not available after 21 August, therefore the models for the following days were not constrained to HCHO, which was instead calculated. Also, measurements of chloroform $\left(\mathrm{CHCl}_{3}\right)$ were not available before 3 August. The omission of peroxides, formaldehyde and chloroform did not influence significantly the calculated concentrations of radicals at night. In the models which were not constrained to the concentrations of oxygenates and hydroperoxides concentrations ("clean" and "full" models), these species were calculated as intermediates and the calculated concentrations were, especially for species with longer lifetimes, more than an order of magnitude less than the measured concentrations, because of the importance of transport.

Dry deposition terms were also included using the values of Derwent et al. (1996) except for peroxides $\left(1.1 \mathrm{~cm} \mathrm{~s}^{-1}\right.$ for $\mathrm{H}_{2} \mathrm{O}_{2}$ and $0.55 \mathrm{~cm} \mathrm{~s}^{-1}$ for organic peroxides), methyl and ethyl nitrate $\left(1.1 \mathrm{~cm} \mathrm{~s}^{-1}\right)$ and $\mathrm{HCHO}\left(0.33 \mathrm{~cm} \mathrm{~s}^{-1}\right)$ (Brasseur et al., 1998). Dry deposition velocity for $\mathrm{CH}_{3} \mathrm{CHO}$ and other aldehydes was assumed to be the same as that for HCHO. A clear diurnal cycle of the boundary layer (BL) was not always recognizable during NAMBLEX and often the synop- tic pattern dominated over the local conditions (Norton et al., 2006). A boundary layer height of $400 \mathrm{~m}$, based on the wind profiler measurements (Norton et al., 2006), was used for the modelled nights. Sensitivity tests showed that BL height was not a significant parameter for the concentration of the modelled species.

Heterogeneous uptake was calculated using Eq. (1) assuming irreversible loss of gas-phase species on aerosol.

$k_{\text {het }}=\frac{A \bar{v} \gamma}{4}$

where $A$ is the total aerosol surface area, $\bar{v}$ is the mean molecular speed and $\gamma$ is the temperature dependent gas/surface reaction probability. The values of $\gamma$ used for $\mathrm{HO}_{2}, \mathrm{NO}_{3}$, $\mathrm{N}_{2} \mathrm{O}_{5}$ were 0.006 (at $298 \mathrm{~K}$ ), 0.004 and 0.032 , respectively (Gratpanche et al., 1996; Allan et al., 1999; Behnke et al., 1997).

The models were used to calculate $\mathrm{OH}, \mathrm{HO}_{2}$, total peroxy radicals $\left(\mathrm{HO}_{2}+\mathrm{RO}_{2}\right), \mathrm{NO}_{3}$ (or $\mathrm{NO}_{3}+\mathrm{N}_{2} \mathrm{O}_{5}$ ) for several nights of the campaign (sunrise was between 05:00 and 06:00 and sunset between 19:30 and 20:30 in August 2002). The model results were compared to the measurements. $\mathrm{OH}$ and $\mathrm{HO}_{2}$ were measured by laser-induced fluorescence (LIF) using the FAGE (Fluorescence Assay by Gas Expansion) technique. During the night the detection limits for the two radicals were $6 \times 10^{4}$ and $1 \times 10^{6}$ molecule $\mathrm{cm}^{-3}$, respectively, with signalto-noise ratio $(\mathrm{S} / \mathrm{N})=1$ and integration time $=20 \mathrm{~s}$ (Smith et al., 2006). Total peroxy radicals $\left(\mathrm{HO}_{2}+\mathrm{RO}_{2}\right)$ were measured by the PERCA (Peroxy Radical Chemical Amplifier) technique with a detection limit of about $0.5 \mathrm{ppt}$ (with $\mathrm{S} / \mathrm{N}$ $=1$ and $1 \mathrm{~min}$ integration time). The FAGE and the PERCA instruments are described, together with a discussion of uncertainties, in Smith et al. (2006) and Fleming et al. (2006), respectively.

$\mathrm{NO}_{3}$ was measured by Differential Optical Absorption Spectroscopy (DOAS). The DOAS instrument was located about $100 \mathrm{~m}$ from the shore with the retro-reflector on an 
Table 2. Average (20:00-05:00) measurements on some selected nights during NAMBLEX. Concentrations in molecule $\mathrm{cm}^{-3}$, temperature in ${ }^{\circ} \mathrm{C}$.

\begin{tabular}{llllll}
\hline Measurements & $1-2$ Aug & $18-19$ Aug & $19-20$ Aug & $20-21$ Aug & $\begin{array}{l}31 \\
\text { Sug-1 }\end{array}$ \\
\hline $\mathrm{O}_{3}$ & $7.8 \times 10^{11}$ & $7.0 \times 10^{11}$ & $6.1 \times 10^{11}$ & $5.8 \times 10^{11}$ & $8.8 \times 10^{11}$ \\
$\mathrm{NO}$ & $3.2 \times 10^{8}$ & $1.5 \times 10^{8}$ & $2.0 \times 10^{8}$ & $1.3 \times 10^{8}$ & $9.2 \times 10^{7}$ \\
$\mathrm{NO}_{2}$ & $7.1 \times 10^{9}$ & $1.8 \times 10^{9}$ & $3.2 \times 10^{9}$ & $6.1 \times 10^{9}$ & $1.6 \times 10^{9}$ \\
$\mathrm{CH}_{4}$ & $5.0 \times 10^{13}$ & $4.7 \times 10^{13}$ & $4.8 \times 10^{13}$ & $4.7 \times 10^{13}$ & $4.6 \times 10^{13}$ \\
$\mathrm{CO}$ & $4.0 \times 10^{12}$ & $2.2 \times 10^{12}$ & $2.0 \times 10^{12}$ & $2.0 \times 10^{12}$ & $3.0 \times 10^{12}$ \\
$\mathrm{H}_{2}$ & $1.4 \times 10^{13}$ & $1.3 \times 10^{13}$ & $1.3 \times 10^{13}$ & $1.3 \times 10^{13}$ & $1.3 \times 10^{13}$ \\
$\mathrm{HCHO}$ (UEA) & $1.7 \times 10^{10}$ & $3.1 \times 10^{9}$ & $3.5 \times 10^{9}$ & $5.6 \times 10^{9}$ & - \\
$\mathrm{HCHO}$ (Leeds) & $3.9 \times 10^{10}$ & $1.5 \times 10^{10}$ & $1.4 \times 10^{10}$ & $1.8 \times 10^{10}$ & - \\
Propene & $6.0 \times 10^{8}$ & $3.6 \times 10^{8}$ & $5.3 \times 10^{8}$ & $5.8 \times 10^{8}$ & $2.5 \times 10^{8}$ \\
DMS & $6.4 \times 10^{8}$ & $2.6 \times 10^{9}$ & $1.0 \times 10^{9}$ & $1.1 \times 10^{9}$ & $1.1 \times 10^{9}$ \\
Acetylene & $7.2 \times 10^{9}$ & $1.5 \times 10^{9}$ & $1.9 \times 10^{9}$ & $1.5 \times 10^{9}$ & $3.5 \times 10^{9}$ \\
Acetaldehyde & $2.3 \times 10^{10}$ & $1.2 \times 10^{10}$ & $1.1 \times 10^{10}$ & $9.9 \times 10^{9}$ & $6.5 \times 10^{9}$ \\
cis-2-butene & $2.9 \times 10^{7}$ & $2.5 \times 10^{7}$ & $2.5 \times 10^{7}$ & $2.8 \times 10^{7}$ & $2.6 \times 10^{7}$ \\
trans-2-butene & $9.8 \times 10^{7}$ & $1.0 \times 10^{8}$ & $1.3 \times 10^{8}$ & $1.4 \times 10^{8}$ & $1.1 \times 10^{8}$ \\
Temperature & 17.5 & 13.8 & 12.8 & 14.3 & 14.1 \\
\hline
\end{tabular}

island about $4 \mathrm{~km}$ west of Mace Head. The total light path was $8.4 \mathrm{~km}$ and $\mathrm{NO}_{3}$ was measured in the $645-680 \mathrm{~nm}$ spectral region with a detection limit of $0.4-0.5 \mathrm{ppt}$ and integration time of $20 \mathrm{~min}$ (Saiz-Lopez et al., 2006). A Cavity RingDown Spectrometer (CRDS) was also present at Mace Head. It was located about $25 \mathrm{~m}$ inland from the DOAS. The CRDS measured $\mathrm{NO}_{3}$ and $\mathrm{NO}_{3}+\mathrm{N}_{2} \mathrm{O}_{5}$ in the spectral region 655$675 \mathrm{~nm}$ with an estimated light path of $\sim 20 \mathrm{~km}$ and a detection limit of approximately $1 \mathrm{ppt}$ (with a $100 \mathrm{~s}$ integration time), depending on the aerosol loading (Bitter et al., 2005). The details of the two instruments are given in Saiz-Lopez et al. (2006); Bitter et al. (2005), where the measurement uncertainties are also discussed.

The modelling of the night-time chemistry in the marine boundary layer was concentrated on a few nights, which can be divided roughly in two periods. The semi-polluted period at the beginning of August (1-5 August), and the unpolluted period during the rest of the campaign (Heard et al., 2006). The semi-polluted period was characterized by comparatively high concentrations of $\mathrm{NO}_{\mathrm{x}}, \mathrm{CO}$, and NMHCs (Table 2). Acetylene, an anthropogenic marker, was 2 to 3 times higher than during other periods of the campaign. The five-day back trajectories showed that the air masses arriving at Mace Head were coming from east-northeast, passing over Northern England and Ireland (Norton et al., 2006). Most of the rest of the campaign and particularly the night 31 August-1 September was characterized by comparatively unpolluted conditions, with low $\mathrm{NO}_{\mathrm{x}}$ and hydrocarbons concentrations (Table 2) and air masses of oceanic origin coming from west, north-west and south-west. More details on the chemical conditions during NAMBLEX can be found in Heard et al. (2006) and a complete discussion of the mete- orology during the campaign can be found in Norton et al. (2006).

\section{$3 \mathrm{OH}, \mathrm{HO}_{2}$ and $\mathrm{RO}_{2}$}

$\mathrm{OH}$ and $\mathrm{HO}_{2}$ were measured during one night (31 August-1 September). $\mathrm{OH}$ was always below the instrumental detection limit $\left(6 \times 10^{4}\right.$ molecule $\left.\mathrm{cm}^{-3}\right)$. Late evening and early morning measurements showed concentrations of the order of $1-2 \times 10^{5}$ molecule $\mathrm{cm}^{-3}$, about twice as much as the modelled concentration during the night (Fig. 1a). The model overestimated the measurements at sunset, but underestimated them at sunrise suggesting the presence of an $\mathrm{OH}$ source unaccounted for or underestimated by the model, such as HONO (Smith et al., 2006).

$\mathrm{HO}_{2}$ concentrations of the order of 1$3 \times 10^{7}$ molecule $\mathrm{cm}^{-3}$ were detected, similar to previous measurements in Mace Head during two nights of the EASE97 campaign $\left(1.5-5 \times 10^{7}\right.$ molecule $\mathrm{cm}^{-3}$, Salisbury et al., 2001). The models overestimated $\mathrm{HO}_{2}$ by about $30-40 \%$ (Fig. 1a). Compared to daytime, when the model overestimated the measurements by about a factor of 2 (Sommariva et al., 2006), the agreement between the model and the measurements is reasonably good and well within the combined uncertainties of the model and of the instrument (25-30\% and 50\%, respectively. Note that the uncertainty of the model is an estimate calculated with a model similar to the "clean" model used in this work (Sommariva et al., 2004). It should be taken as a lower limit due to the influence of alkenes at night and the importance of the $\mathrm{O}_{3}+$ alkenes reactions as a night-time radical source. In the earlier 

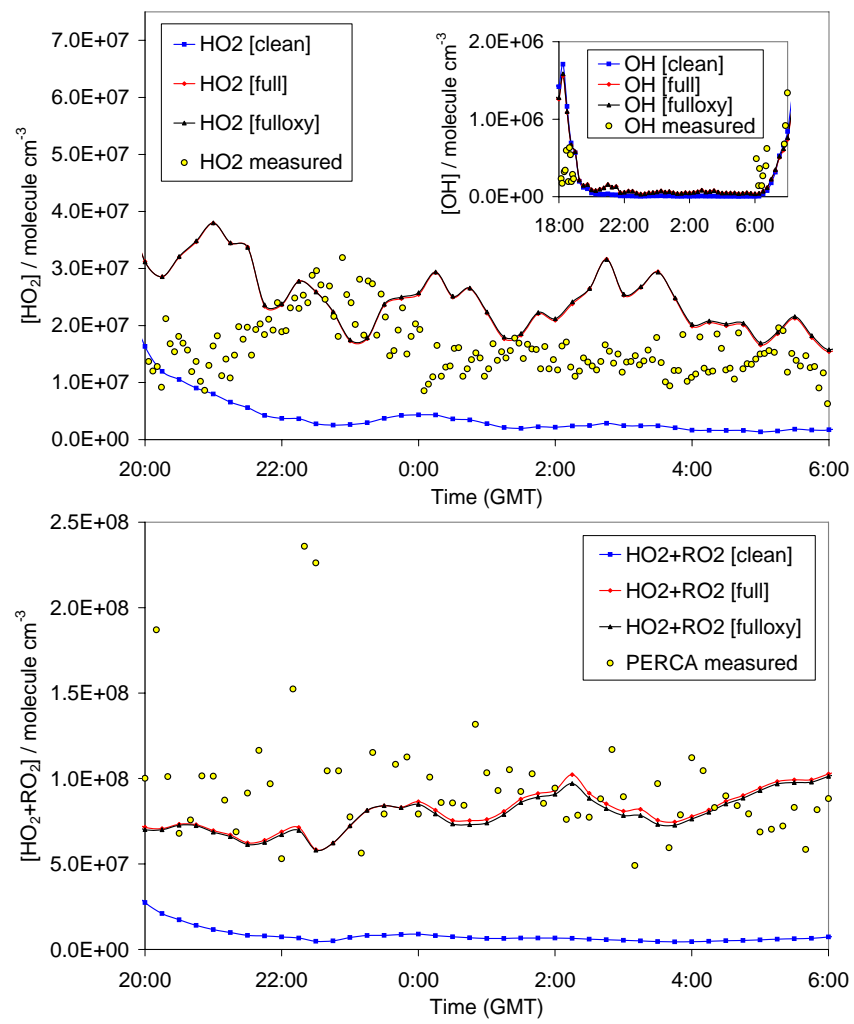

Fig. 1. Model-measurement comparison for $\mathrm{OH}, \mathrm{HO}_{2}$ (a) and $\mathrm{HO}_{2}+\mathrm{RO}_{2}$ (b) during the night 31 August-1 September.

analysis (Sommariva et al., 2004) ozone photolysis, which suffers from much smaller uncertainties, was the main radical source).

PERCA measurements were taken every night during the campaign. The comparisons with the model results are shown in Figs. 1b and 2a. The agreement between modelled and measured $\mathrm{HO}_{2}+\mathrm{RO}_{2}$ was within 15-30\% during most of the modelled nights. Contrary to the day-time, the model showed a tendency to underestimate the PERCA measurements during the night (see Fig. 4b in Fleming et al., 2006). During the night 20-21 August the model underestimated the measurements by about $50 \%$ (Figs. 1b-2a). On some occasions measured $\left[\mathrm{HO}_{2}+\mathrm{RO}_{2}\right]$ increased throughout the night, which appeared to be related to $\mathrm{NO}_{\mathrm{x}}$ events (e.g. 17-18 August). Fleming et al. (2006) showed that the measured peroxy radicals concentration during the night was generally higher at higher $\left[\mathrm{NO}_{\mathrm{x}}\right]$. The models were not able to reproduce the measured peroxy radicals concentrations during these $\mathrm{NO}_{\mathrm{x}}$ events, which might point to some neglected source of peroxy radicals in the chemical mechanism or to the presence of some unmeasured $\mathrm{RO}_{2}$ precursor.

The speciation of modelled peroxy radicals during NAMBLEX, showed that $\mathrm{CH}_{3} \mathrm{O}_{2}$ was the dominant radical during the night. In the unpolluted period $\mathrm{CH}_{3} \mathrm{O}_{2}$ was up to $60 \%$ of $\mathrm{HO}_{2}+\mathrm{RO}_{2}$, while $\mathrm{HO}_{2}$ was about $20 \%$ of $\mathrm{HO}_{2}+\mathrm{RO}_{2}$. This was approximately the reverse of the day-time proportion
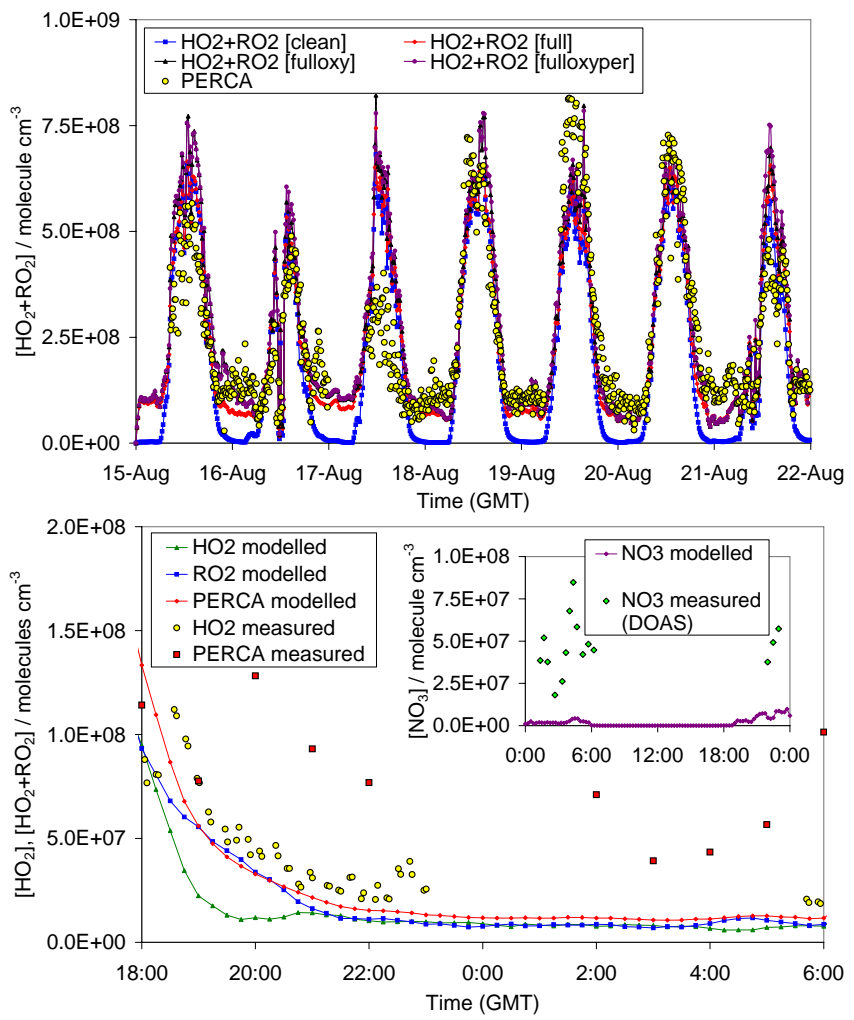

Fig. 2. Model-measurement comparison for $\mathrm{HO}_{2}+\mathrm{RO}_{2}$ during the period 15-21 August of NAMBLEX (a). Model-measurement comparison for $\mathrm{NO}_{3}, \mathrm{HO}_{2}$ and $\mathrm{HO}_{2}+\mathrm{RO}_{2}$ during the night 15-16 February 1999 of SOAPEX-2 (b). The equivalent of the "clean" model was used for the SOAPEX-2 campaign (Sommariva et al., 2004).

and in good agreement with the results of the EASE97 campaign by Salisbury et al. (2001). During the semi-polluted period $\mathrm{CH}_{3} \mathrm{O}_{2}$ was up to $40 \%$ of $\mathrm{HO}_{2}+\mathrm{RO}_{2}$, while $\mathrm{HO}_{2}$ was about $40 \%$ of $\mathrm{HO}_{2}+\mathrm{RO}_{2}$ indicating a faster production of inorganic radicals in presence of higher $\mathrm{NO}_{\mathrm{x}}$ and $\mathrm{NMHCs}$ concentrations. The modelled $\mathrm{HO}_{2} /\left(\mathrm{HO}_{2}+\mathrm{RO}_{2}\right)$ ratio was about $50 \%$ higher than the measured ratio, as a consequence of the overestimation of $\mathrm{HO}_{2}$ (Fleming et al., 2006).

Comparing the results of the different models (Table 1) it is clear that the difference between the "full", "fulloxy" and "fulloxyper" models was negligible (Figs. 1 and 2a), indicating that additional constraints of oxygenates and peroxides did not influence significantly the concentrations of $\mathrm{HO}_{2}$ and $\mathrm{RO}_{2}$. However for the "clean" model, which was constrained only to $\mathrm{CO}$ and $\mathrm{CH}_{4}$, calculated concentrations of $\mathrm{HO}_{2}$ (Fig. 1a) and $\mathrm{HO}_{2}+\mathrm{RO}_{2}$ (Figs. 1a and $2 \mathrm{a}$ ) were about an order of magnitude lower than the concentrations calculated by the "full" and "fulloxy" models. This was due to the fact that the only peroxy radical of the "clean" model was $\mathrm{CH}_{3} \mathrm{O}_{2}$, which mainly came from $\mathrm{CH}_{4}$ oxidation, a very slow reaction at night $\left(k_{\mathrm{CH}_{4}+\mathrm{NO}_{3}}<1 \times 10^{-18} \mathrm{~cm}^{3}\right.$ molecule ${ }^{-1} \mathrm{~s}^{-1}$, Atkinson et al., 2003). 

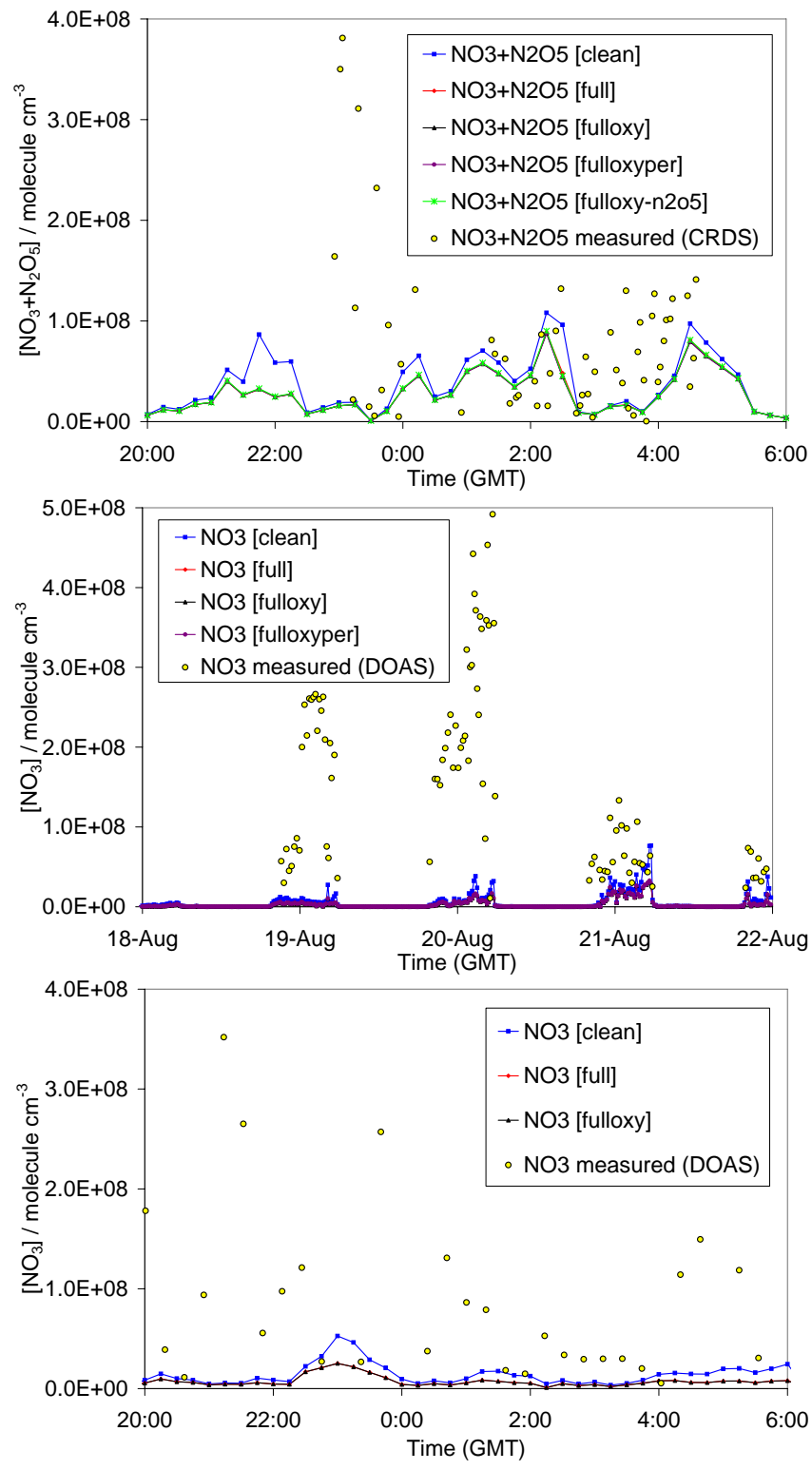

Fig. 3. Model-measurement for $\mathrm{NO}_{3}+\mathrm{N}_{2} \mathrm{O}_{5}$, also showing the impact of $\mathrm{N}_{2} \mathrm{O}_{5}$ uptake, during the night 1-2 August (a) and for $\mathrm{NO}_{3}$ during the period 18-22 August (b) and the night 31 August-1 September (c). The CRDS uncertainty was $\pm 1 \times 10^{8}$ molecule $\mathrm{cm}^{-3}$ before midnight and $\pm 3.8 \times 10^{7}$ molecule $\mathrm{cm}^{-3}$ after midnight on 1-2 August.

Similar results were obtained during the baseline periods of the SOAPEX-2 campaign in the Southern Hemisphere using a model similar to the "clean" model (Sommariva et al., 2004). On one occasion (15-16 February 1999), late evening and early morning measurements of $\mathrm{OH}$ and $\mathrm{HO}_{2}$ were made, showing late evening concentrations of $\mathrm{HO}_{2}$ about a factor of two larger than the predictions of the "clean" model (Fig. 2b). The model underestimated $\mathrm{HO}_{2}+\mathrm{RO}_{2}$ by about almost an order of magnitude, a similar factor to that found when using the "clean" model for NAMBLEX (Fig. 1b).
Since the more detailed models ("full", "fulloxy" and "fulloxyper") provide much better agreement with the NAMBLEX observations of $\mathrm{HO}_{2}+\mathrm{RO}_{2}$, this observation suggests that even in the extremely clean conditions of Cape Grim (Sommariva et al., 2004) $\mathrm{CO}$ and $\mathrm{CH}_{4}$ alone cannot account for the radical budget and even low concentrations of NMHCs play a significant role.

\section{$\begin{array}{lll}4 & \mathrm{NO}_{3}\end{array}$}

The nitrate radical was measured for many nights during NAMBLEX by DOAS and CRDS (Saiz-Lopez et al., 2006; Bitter et al., 2007). Data from the CRDS instrument were available only for the initial semi-polluted period of the campaign when the concentrations were higher (Table 2). The model-measurements comparisons are shown in Fig. 3.

The models always underestimated the DOAS measurements of $\left[\mathrm{NO}_{3}\right]$, on average by about a factor of $4-5$ up to a factor of 10 (Figs. 3b-c). On some nights, like 18-19 and 1920 August, the modelled concentrations of $\mathrm{NO}_{3}$ were up to 60 times lower than the DOAS measurements. This was similar to the results obtained for the one night in the SOAPEX-2 campaign which was modelled (15-16 February 1999) and for which $\mathrm{NO}_{3}$ measurements were available (Fig. 2b).

The agreement between modelled $\mathrm{NO}_{3}+\mathrm{N}_{2} \mathrm{O}_{5}$ and the measurements by CRDS was generally better (Fig. 3a). Modelled concentrations were typically within $30-50 \%$ of the measurements, with the model showing a tendency to underestimate the measurements. Note that on the night 1-2 August the high CRDS measurements before midnight (Fig. 3a) were subject to a larger uncertainty than the measurements taken later in the night, due to the higher aerosol optical depth (Bitter et al., 2007 ${ }^{1}$ ).

A detailed comparison between the DOAS and CRDS measurements and a discussion of the possible reasons for the different $\left[\mathrm{NO}_{3}\right]$ measured by the two instruments is presented in Bitter et al. (2007) ${ }^{1}$. An important point to note is that while the DOAS measurements were averages over a long path $(8.4 \mathrm{~km}$ at Mace Head) crossing a branch of sea, the CRDS measurements were point measurements made about $100 \mathrm{~m}$ from the shore (Heard et al., 2006). The fact that the model-DOAS discrepancy was similar in such diverse conditions as SOAPEX-2 (Sommariva et al., 2004) and NAMBLEX (Table 2) in contrast with the good agreement between the model and the CRDS point measurements suggests that the zero-dimensional approach used in this work might not be suitable to model DOAS measurements.

Under the relatively low $\left[\mathrm{NO}_{2}\right]$ conditions at Mace Head, $\mathrm{NO}_{3}$ and $\mathrm{N}_{2} \mathrm{O}_{5}$ rapidly equilibrate (Eq. R3) and any loss of $\mathrm{N}_{2} \mathrm{O}_{5}$ resulted in the removal of $\mathrm{NO}_{3}$ from the system. $\mathrm{N}_{2} \mathrm{O}_{5}$ can be removed by reaction with $\mathrm{H}_{2} \mathrm{O}$ and by uptake on aerosol. Previous studies have shown that, under certain conditions (semi-polluted air masses with little marine influence), removal of $\mathrm{N}_{2} \mathrm{O}_{5}$ can be a major loss pathway 
for $\mathrm{NO}_{3}$ (Allan et al., 1999, 2000). Semi-polluted conditions were experienced at the beginning of the NAMBLEX campaign (1-2 August). To test the impact of $\mathrm{N}_{2} \mathrm{O}_{5}$ uptake on modelled $\left[\mathrm{NO}_{3}+\mathrm{N}_{2} \mathrm{O}_{5}\right]$ the model was run with an uptake rate coefficient for $\mathrm{N}_{2} \mathrm{O}_{5}$ equal to 0.016 (in the base model $\left.\gamma_{\mathrm{N}_{2} \mathrm{O}_{5}}=0.032\right)$. The effect on modelled $\left[\mathrm{NO}_{3}+\mathrm{N}_{2} \mathrm{O}_{5}\right]$ was negligible (model "fulloxy-n2o5" in Fig. 3a), because heterogeneous loss, under these conditions, was not a major loss process for the coupled $\mathrm{NO}_{3} / \mathrm{N}_{2} \mathrm{O}_{5}$ system.

An important issue in night-time chemistry is the concentration of nitric oxide. NO rapidly reacts with radicals, for which there are few night-time sources, and with ozone. With $30 \mathrm{ppb}$ of $\mathrm{O}_{3}$, NO has a lifetime of about $1 \mathrm{~min}$ at $283 \mathrm{~K}$. Its concentration is therefore expected to be extremely low during the night. However, this is not always the case, since NO local sources might be present. During NAMBLEX, NO concentrations above the detection limit of the instrument (3$4 \mathrm{ppt}$ ) were often detected during the night. The night-time average mixing ratio was about $15-20 \mathrm{ppt}$ during the semipolluted period and about $6.5-7 \mathrm{ppt}$ during the unpolluted period. This suggests the presence of a local source of NO, possibly emissions from the soil during the night.

The emission of $\mathrm{NO}$ from soils might provide an important $\mathrm{NO}_{3}$ sink (via the $\mathrm{NO}+\mathrm{NO}_{3}$ reaction), particularly in Ireland, because of the presence of peaty soils around Mace Head (Williams and Fehsenfeld, 1991; Williams et al., 1992; Regina et al., 1998). Since the DOAS sampled over the sea, while the CRDS sampled over the land, local NO soil emissions might explain the difference between the two instrument's measurements and the underestimation of the DOAS observations by the model. This hypothesis is discussed in more detail in Bitter et al. $(2007)^{1}$, who used a simple box model to show how NO emitted over land could suppress $\mathrm{NO}_{3}$ at the levels observed by CRDS but, as the air mass was advected over the sea and away from the NO source by off-shore winds, the concentration of $\mathrm{NO}_{3}$ would steadily increase to the levels observed by DOAS. Conversely under a sea-breeze, the higher $\mathrm{NO}_{3}$ concentrations maintained over the sea are rapidly titrated by the $\mathrm{NO}$ emissions at the shore when the air mass arrives over the land (Bitter et al., 2007) ${ }^{1}$.

The "clean" and the "fulloxy" models were therefore run with measured $\mathrm{NO}$ during the day and $[\mathrm{NO}]=0$ during the night to understand the impact of nitric oxide on modelled $\mathrm{NO}_{3}$ and to see if this could explain the discrepancy between the model and the DOAS measurements. The results of these test runs are shown in Fig. 4. Also shown are the results of model runs with $[\mathrm{DMS}]=0$ and with both $[\mathrm{NO}]$ and $[\mathrm{DMS}]=0$.

Figure 4 suggests that setting [DMS] to zero did not have a significant effect on the calculated $\mathrm{NO}_{3}$, except when the models were also constrained to zero [NO]. In fact, when the models were constrained to measured NO, the main fate of $\mathrm{NO}_{3}$ was the reaction with NO. The models showed that when both [DMS] and [NO] were set to zero, $\mathrm{NO}_{3}$ mainly reacted with NMHCs. These reactions were slower, result-
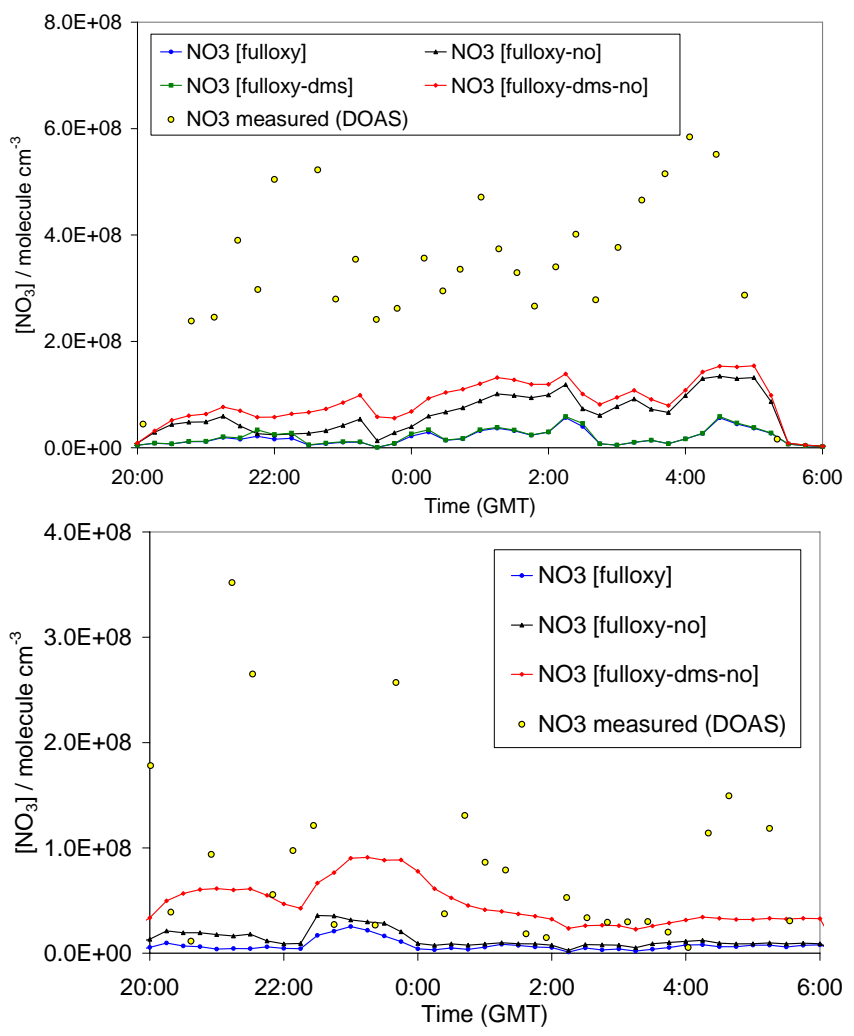

Fig. 4. Model-measurement comparison for $\mathrm{NO}_{3}$ showing the impact of $[\mathrm{NO}]=0$ and $[\mathrm{DMS}]=0$ during the night $1-2$ August (a) and 31 August-1 September (b).

ing in a higher $\left[\mathrm{NO}_{3}\right]$ and the models became more sensitive to DMS. Therefore, when both [DMS] and [NO] were set to zero, $\left[\mathrm{NO}_{3}\right]$ became 3-4 times larger than when $\mathrm{NO}$ was present. However, this was not enough to increase the calculated $\left[\mathrm{NO}_{3}\right]$ up to the values measured by the DOAS and caused an overestimation of the CRDS measurements (about $40-50 \%$ and up to a factor of 3).

Another issue which might be significant in explaining the differences between the DOAS, the CRDS and the models is the vertical profile of $\mathrm{NO}_{3}$. Saiz-Lopez et al. (2006) observed a positive vertical $\mathrm{NO}_{3}$ gradient over Mace Head, which they attributed in part to the temperature and $\mathrm{NO}_{2}$ vertical profile and in part to the reaction of $\mathrm{NO}_{3}$ with DMS, whose concentration was higher near the sea surface (Purvis et al., 2005). The $\mathrm{NO}_{3}$ gradient could also cause a downward motion of $\mathrm{NO}_{3}$ over the ocean. This could in part explain the fact that the DOAS measurements were higher than the CRDS measurements (Bitter et al., 2007) ${ }^{1}$. In fact, while the heights of the CRDS and of the DOAS telescope were roughly the same, the DOAS retro-reflector was located at a higher position, so the average height of measurement for DOAS measurements was greater than that of the CDRS. One contributor to a vertical gradient in $\left[\mathrm{NO}_{3}\right]$ would be a decrease in NO with altitude, arising from a surface source, coupled with loss of NO by reaction with ozone. A significant vertical 


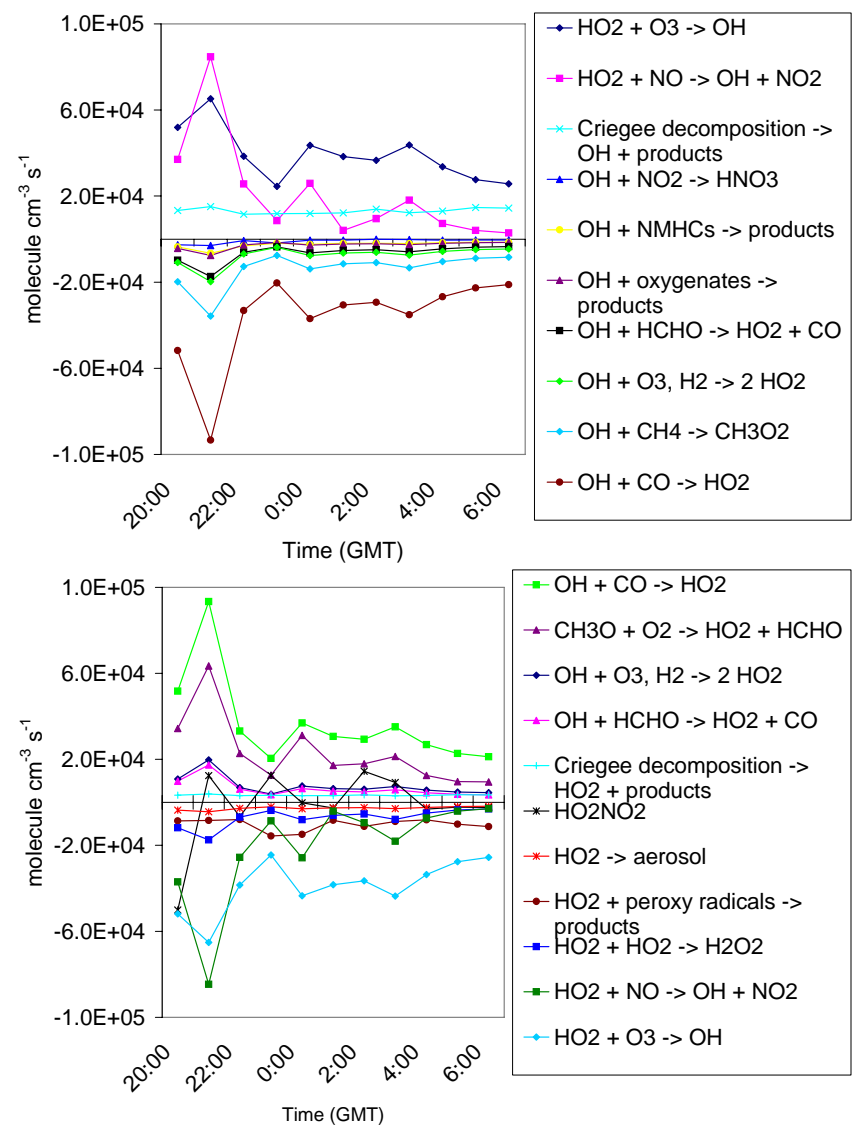

Fig. 5. Rates of production and destruction of $\mathrm{OH}$ (a) and $\mathrm{HO}_{2}$ (b) during the night of 31 August-1 September. $\mathrm{OH}+\mathrm{O} 3, \mathrm{H} 2 \rightarrow 2 \mathrm{HO} 2$ indicates the sum of the rates of $\mathrm{OH}+\mathrm{O}_{3} \rightarrow \mathrm{HO}_{2}$ and $\mathrm{OH}+\mathrm{H}_{2} \rightarrow \mathrm{HO}_{2}$.

gradient in $\left[\mathrm{NO}_{3}\right]$ would compromise the zero-dimensional model used in this study and lead to poorer prediction of the measured $\left[\mathrm{NO}_{3}\right]$. The approach, which relies on the constraint of longer-lived species to measured values, works best for very short-lived modelled species such as $\mathrm{OH}$. For longer lived radicals, such as $\mathrm{NO}_{3}$, significant transport along a concentration gradient on timescales comparable to the radical lifetime would not be captured by the model.

\section{Analysis of the radical fluxes}

The rates of production and destruction of modelled $\mathrm{OH}$, $\mathrm{HO}_{2}$ and $\mathrm{NO}_{3}$ were calculated for the nights 1 and $2 \mathrm{Au}-$ gust, characterized by semi-polluted conditions and higher $\left[\mathrm{NO}_{3}\right]$, and 31 August and 1 September, characterized by unpolluted conditions and lower $\left[\mathrm{NO}_{3}\right]$ (Table 2). The objective of the analysis was to identify the most important reactions and the processes driving the night-time chemistry under those conditions. The "fulloxy" model was used as reference. The results of the rate of production and destruction analysis are shown in Fig. 5 for $\mathrm{HO}_{\mathrm{x}}$ during the night 31
August-1 September and in Fig. 6 for $\mathrm{NO}_{3}$ during the nights of 1-2 August and 31 August-1 September.

There were essentially two interacting chain cycles, one directly linking $\mathrm{OH}$ to $\mathrm{HO}_{2}$ via $\mathrm{CO}$, the other proceeding via $\mathrm{RO}_{2}$, with $\mathrm{CH}_{3} \mathrm{O}_{2}$ as the main immediate precursor of $\mathrm{HO}_{2}$. The time constant of the former was quite short, of the order of $1 \mathrm{~s}$, and was largely determined by the $\mathrm{OH}$ reactions shown in Fig. 5a, primarily involving $\mathrm{CO}$, but also $\mathrm{HCHO}, \mathrm{O}_{3}$ and $\mathrm{H}_{2}$. The route through $\mathrm{CH}_{3} \mathrm{O}_{2}$ involved not only reaction of $\mathrm{OH}$ with $\mathrm{CH}_{4}$, but also with NMHCs. There were also two other, longer time constants associated with the chain cycle, involving the conversion of $\mathrm{CH}_{3} \mathrm{O}_{2}$ to $\mathrm{HO}_{2}$ by reaction with $\mathrm{NO}$ and of $\mathrm{HO}_{2}$ to $\mathrm{OH}$ by reaction with $\mathrm{O}_{3}$ and $\mathrm{NO}$, with the latter decreasing in importance with time. If there was no source term, the coupled radical pool would slowly decay, via both peroxy-peroxy and $\mathrm{OH}+\mathrm{NO}_{2}$ reactions. In the models constrained to measured hydrocarbons ("full", "fulloxy" and "fulloxyper") alkenes provided such a radical source. Formation of $\mathrm{OH}$ and $\mathrm{CH}_{3} \mathrm{O}_{2}$ via the Criegee intermediates formed from the reactions of alkenes (mainly propene, c-2-butene, t-2-butene, c-2-pentene, t-2-pentene) with ozone helped to maintain the radical concentrations, although there was generally a slow decrease with time.

Fleming et al. (2006) calculated the fluxes of radicals from alkenes $+\mathrm{O}_{3}$ and alkenes $+\mathrm{NO}_{3}$ during several nights of the NAMBLEX campaign. They showed that ozone reactivity dominated the formation of radicals most of the nights, except when the $\mathrm{NO}_{3}$ concentration was high, such as in the semi-polluted period at the beginning of the campaign. This is in broad agreement with the results of the reaction rate analysis discussed above (it must be noted that Fleming et al. (2006) used $\left[\mathrm{NO}_{3}\right]$ as measured by DOAS, which was typically an order of magnitude higher than the modelled $\left[\mathrm{NO}_{3}\right]$ used here).

On the night of 1-2 August, the main formation and destruction routes for $\mathrm{NO}_{3}$ were $\mathrm{NO}_{2}+\mathrm{O}_{3}$ and $\mathrm{NO}_{3}+\mathrm{NO}$ respectively (Fig. 6). The $\mathrm{NO}_{3}+\mathrm{NO}_{2} \rightleftharpoons \mathrm{N}_{2} \mathrm{O}_{5}$ equilibration was rapid but led to a net sink for $\mathrm{NO}_{3}$, because of the loss of $\mathrm{N}_{2} \mathrm{O}_{5}$ by hydrolysis and heterogeneous uptake. On 31 August-1 September, the $\mathrm{N}_{2} \mathrm{O}_{5}$ loss was less significant than on 1-2 August, so that the forward and reverse steps in the equilibration balanced. The main losses of $\mathrm{NO}_{3}$ on both nights were the reactions with NO and with DMS. On the unpolluted night 31 August-1 September the two reaction rates were comparable $\left(\sim 5 \times 10^{3}\right.$ molecule $\left.\mathrm{cm}^{-3} \mathrm{~s}^{-1}\right)$, while on the semi-polluted night 1-2 August the reaction with NO was about a factor of 4 faster (Fig. 6). In fact, on this night the concentration of NO was generally higher (about a factor of 3 during the night), as polluted air arrived at Mace Head from the north-east, and the DMS concentration was lower. Other sinks for $\mathrm{NO}_{3}$ were the reactions with a range of NMHCs (mainly alkenes like but-1-ene and t-2-butene and aromatics like phenol and cathecols) and peroxy radicals $\left(\mathrm{HO}_{2}\right.$ and $\mathrm{CH}_{3} \mathrm{O}_{2}$ ). 

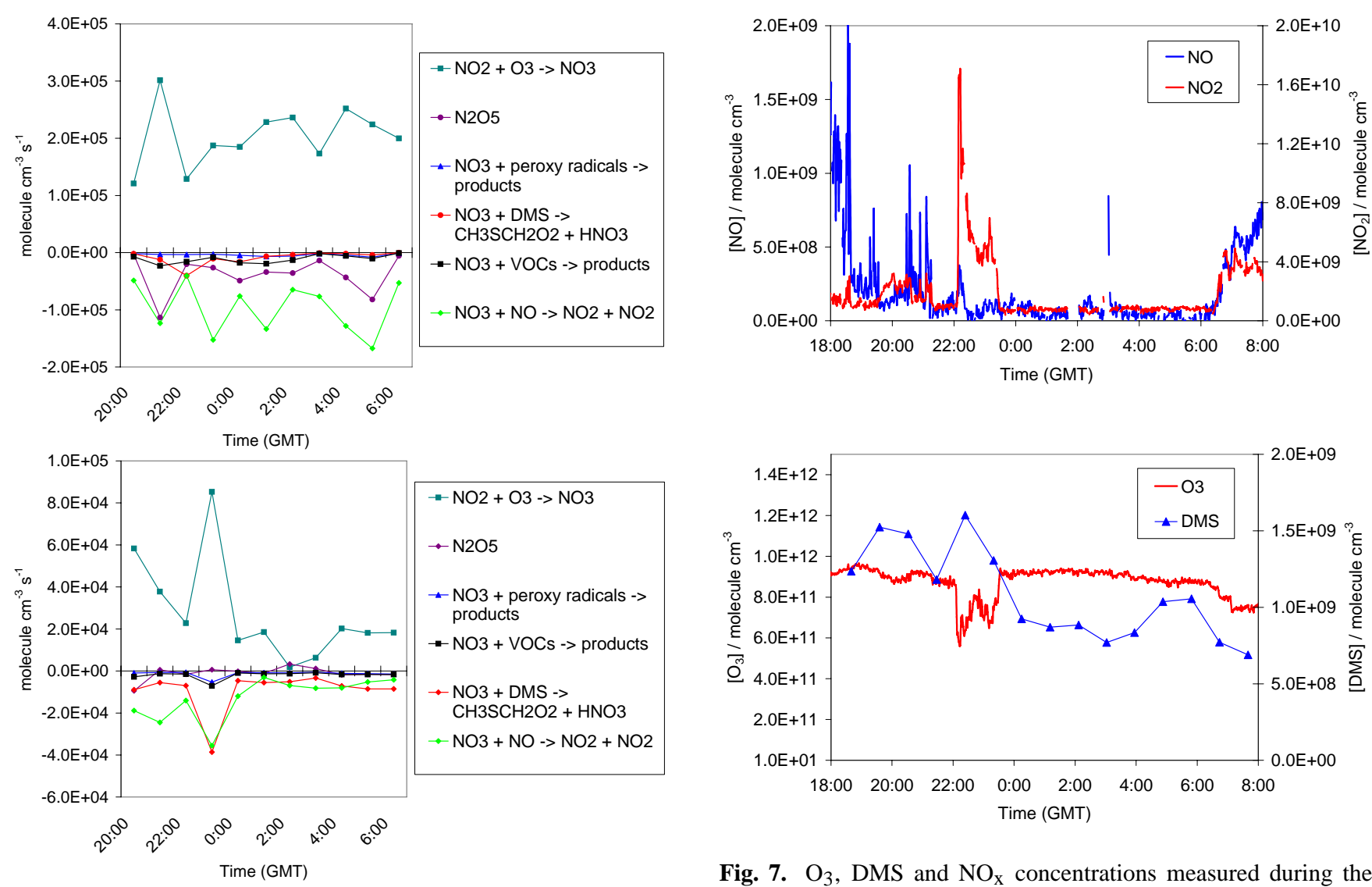

Fig. 6. Rates of production and destruction of $\mathrm{NO}_{3}$ during the night of 1-2 August (a) and during the night of 31 August-1 September (b).

\section{A case-study night}

Measurements of $\mathrm{HO}_{2}, \mathrm{HO}_{2}+\mathrm{RO}_{2}$ and $\mathrm{NO}_{3}$ were all made on the night between 31 August and 1 September. $\mathrm{OH}$ was also measured, but was always below the detection limit. A large spike of $\mathrm{NO}_{2}$ occurred in the middle of the night allowing the couplings between the species and the cycles of $\mathrm{HO}_{\mathrm{x}}$ and $\mathrm{NO}_{3}$ to be studied.

Between 22:00 and 24:00 on 31 August the measured concentration of $\mathrm{NO}_{2}$ rose from its "normal" value of $40 \mathrm{ppt}$ to about 300 ppt. The concentration of NO did not change as much (Fig. 7). The spike appeared to be related to a change in the local wind direction from $\sim 200^{\circ}$ (S-SW, from the open sea) to $\sim 150^{\circ}$ (S-SE, along the coastline). Since NO is the major component of $\mathrm{NO}_{\mathrm{x}}$ emitted from both combustion and soil sources, the most probable explanation was an upwind source of $\mathrm{NO}$, which was converted into $\mathrm{NO}_{2}$ by reaction with $\mathrm{O}_{3}$ during transit to the measurement site. Figure 8 shows the reactions of the most important species in the night-time chemistry on 31 August-1 September (Sect. 5) and their connections via ozone and $\mathrm{NO} . \mathrm{O}_{3}$ in particular had a double role. It converted $\mathrm{HO}_{2}$ to $\mathrm{OH}$, and also reacted with $\mathrm{NO}_{2}$ to generate $\mathrm{NO}_{3} . \mathrm{NO}_{3}$ and $\mathrm{NO}_{2}$ were linked through

Fig. 7. $\mathrm{O}_{3}, \mathrm{DMS}$ and $\mathrm{NO}_{\mathrm{x}}$ concentrations measured during the night of 31 August-1 September.

the reaction $\mathrm{NO}_{3}+\mathrm{NO}$ and through the equilibrium of $\mathrm{N}_{2} \mathrm{O}_{5}$. Thus the change in the concentration of $\mathrm{NO}_{2}$ quickly propagated through the cycles to affect all of the shorter lived species. The fluxes during the $\mathrm{NO}_{2}$ event (23:00) and under "normal" conditions (24:00) are shown in Fig. 8.

\section{Conclusions}

Night-time measurements of radicals were made during a field campaign (NAMBLEX) in a marine environment in the Northern Hemisphere. $\mathrm{OH}$ was always below the detection limit $\left(6 \times 10^{4}\right.$ molecule $\left.\mathrm{cm}^{-3}\right)$, but $\mathrm{HO}_{2}$ concentrations of $1-$ $3 \times 10^{7}$ molecule $\mathrm{cm}^{-3}$ were measured during one night (31 August-1 September). $\mathrm{HO}_{2}+\mathrm{RO}_{2}$ and $\mathrm{NO}_{3}$ were measured on several nights. On the night of 31 August-1 September simultaneous measurements of $\mathrm{HO}_{2}, \mathrm{HO}_{2}+\mathrm{RO}_{2}$ and $\mathrm{NO}_{3}$ were available, together with many other supporting measurements, allowing a thorough study of night-time chemistry. The radicals concentrations were calculated using a set of zero-dimensional box-models, based on the Master Chemical Mechanism and constrained to measured species and parameters.

The agreement between the model and the measurements was reasonably good for $\mathrm{HO}_{2}$, with a tendency to overestimate the measurements by less than $40 \%$. The agreement 


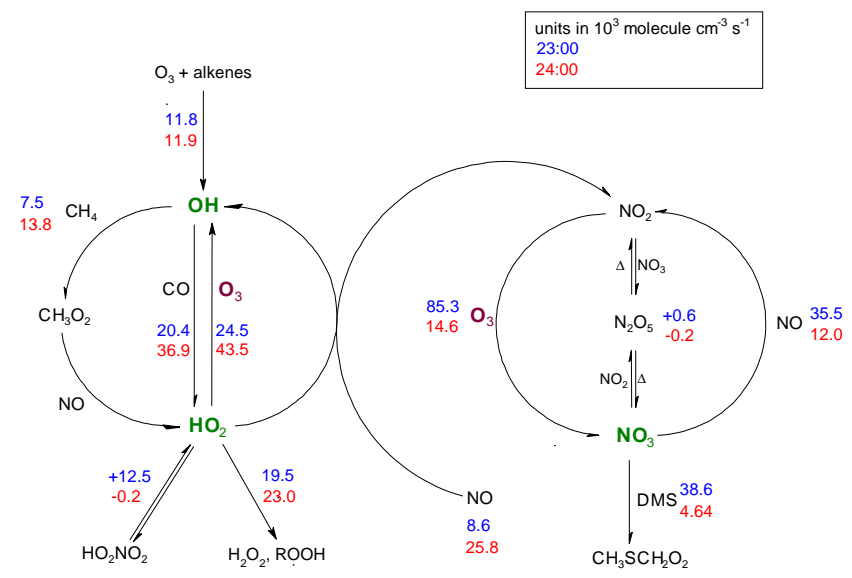

Fig. 8. Radical fluxes during the night of 31 August-1 September at 23:00 (in the middle of the $\mathrm{NO}_{2}$ spike) and 24:00 (after the $\mathrm{NO}_{2}$ spike). Note that $\mathrm{HO}_{2} \mathrm{NO}_{2}$ was not in balance with $\mathrm{HO}_{2}$ at 23:00 because the $\mathrm{NO}_{2}$ spike's maximum occurred around 22:30 (Fig. 7) and therefore at 23:00 $\mathrm{HO}_{2} \mathrm{NO}_{2}$ was decomposing to reach a new equilibrium.

with $\mathrm{HO}_{2}+\mathrm{RO}_{2}$ was more variable, but within $15-30 \%$ during most of the nights. A model containing only $\mathrm{CO}$ and $\mathrm{CH}_{4}$ chemistry always underestimated both $\left[\mathrm{HO}_{2}\right]$ and $\left[\mathrm{HO}_{2}+\mathrm{RO}_{2}\right]$ by about an order of magnitude, showing that most of the peroxy radicals generated during the night derived from the oxidation of NMHCs. The peroxy radicals with the highest contribution to the total peroxy radicals concentration were $\mathrm{HO}_{2}$ (20\% on unpolluted nights and $40 \%$ on semi-polluted nights) and $\mathrm{CH}_{3} \mathrm{O}_{2}(60 \%$ on unpolluted nights and $40 \%$ on semi-polluted nights).

The measurements indicated that the radical concentrations remained more or less constant throughout the night, suggesting a nocturnal radical source. The models constrained to measured hydrocarbons showed that the reactions of $\mathrm{O}_{3}$ with alkenes (mainly propene, butenes and pentenes) resulted in a slow but steady source of $\mathrm{OH}$ during the night which compensated the slow removal of radicals via peroxyperoxy and $\mathrm{OH}+\mathrm{NO}_{2}$ reactions.

The model consistently underestimated $\left[\mathrm{NO}_{3}\right]$ measured by DOAS by a factor of 5-10 or more. The agreement with the CRDS measurements during NAMBLEX was much better, within $30-50 \%$. Scavenging of $\mathrm{NO}_{3}$ by $\mathrm{NO}$ over land was explored as one of the possible explanations for the discrepancy between the two instruments and with the model. Reaction with $\mathrm{NO}$ was the main loss process for $\mathrm{NO}_{3}$ during the night 31 August-1 September, followed by the reaction with DMS. When the model was run with $[\mathrm{NO}]=0, \mathrm{NO}_{3}$ mainly reacted with DMS resulting in an increase in modelled $\mathrm{NO}_{3}$ of about $50 \%$. With $[\mathrm{DMS}]=0$, modelled $\mathrm{NO}_{3}$ increased by about $70-80 \%$ and the main losses for the nitrate radical became the reactions with a variety of alkenes, aromatics and peroxy radicals or the uptake on aerosol. The only source of $\mathrm{NO}_{3}$ was the reaction of $\mathrm{NO}_{2}$ with $\mathrm{O}_{3}$.
On 31 August-1 September a spike of $\mathrm{NO}_{2}$ of up to $300 \mathrm{ppt}$ allowed an examination of the coupling between $\mathrm{NO}_{3}$ and $\mathrm{HO}_{\mathrm{x}}$. The increase in $\mathrm{NO}_{2}$ caused an acceleration of the reaction with $\mathrm{O}_{3}$, increasing the production of $\mathrm{NO}_{3}$ and hence the rate of formation of peroxy radicals especially through its reaction with DMS.

Acknowledgements. We gratefully acknowledge the support and the help of the Mace Head Atmospheric Research Station during the NAMBLEX campaign, particularly G. Spain. Thanks to G. P. Johnson for technical assistance with the operation of the FAGE instrument during the campaign. We also would like to thank G. Mills for help with the $\mathrm{NO}_{\mathrm{x}}$ dataset, J. Methven for providing the back trajectories and the Universities of Leeds, Leicester, East Anglia, Manchester and York for the use of their data. R. Sommariva acknowledges the University of Leeds for a scholarship. D. E. Heard would like to thank the Royal Society for a University Research Fellowship and some equipment funding.

Edited by: W. T. Sturges

\section{References}

Allan, B. J., Carslaw, N., Coe, H., Burgess, R. A., and Plane, J. M. C.: Observations of the nitrate radical in the marine boundary layer, J. Atmos. Chem., 33, 129-154, 1999.

Allan, B. J., McFiggans, G., Plane, J. M. C., Coe, H., and McFadyen, G. G.: The nitrate radical in the remote marine boundary layer, J. Geophys. Res., 105, 24 191-24 204, 2000.

Atkinson, R. and Arey, J.: Atmospheric degradation of volatile organic compounds, Chem. Rev., 103, 4605-4638, 2003.

Atkinson, R., Baulch, D. L., Cox, R. A., Crowley, J. N., Hampson Jr., R. F., Kerr, J. A., Rossi, M. J., and Troe, J.: Summary of evaluated kinetic and photochemical data for atmospheric chemistry, Tech. rep., IUPAC Subcommittee on Gas Kinetic Data Evaluation for Atmospheric Chemistry, http://www.copernicus.org/ EGU/acp/acpd/special_issue8.html, 2003.

Behnke, W., George, C., Scheer, V., and Zetzsch, C.: Production and decay of $\mathrm{ClNO}_{2}$ from the reaction of gaseous $\mathrm{N}_{2} \mathrm{O}_{5}$ with $\mathrm{NaCl}$ solution: bulk and aerosol experiments, J. Geophys. Res., 102, 3795-3804, 1997.

Berresheim, H., Elste, T., Tremmel, H. G., Allen, A. G., Hansson, H.-C., Rosman, K., Maso, M. D., Mäkelä, J. M., and Kulmala, M.: Gas-aerosol relationship of $\mathrm{H}_{2} \mathrm{SO}_{4}$, MSA, and $\mathrm{OH}$ : observations in the coastal marine boundary layer at Mace Head, Ireland, J. Geophys. Res., 107, 8100, 2002.

Bitter, M., Ball, S. M., Povey, I. M., and Jones, R. L.: A broadband cavity ringdown spectrometer for in-situ measurements of atmospheric trace gases, Atmos. Chem. Phys., 5, 2547-2560, 2005, http://www.atmos-chem-phys.net/5/2547/2005/.

Brasseur, G. P., Hauglustaine, D. A., Walters, S., Rasch, P. J., Muller, J. F., Granier, C., and Tie, X. X.: MOZART, a global chemical transport model for ozone and related chemical tracers - 1. Model description, J. Geophys. Res., 103, 28 265-28 289, 1998.

Brown, S. S., Stark, H., Ryerson, T. B., Williams, E. J., Nicks, D. K., Trainer, M., Fehsenfeld, F. C., and Ravishankara, A. R.: Nitrogen oxides in the nocturnal boundary layer: simultaneous 
in situ measurements of $\mathrm{NO}_{3}, \mathrm{~N}_{2} \mathrm{O}_{5}, \mathrm{NO}_{2}, \mathrm{NO}$ and $\mathrm{O}_{3}$, J. Geophys. Res., 108(D9), 4299, doi:10.1029/2002JD002917, 2003.

Brown, S. S., Dibb, J. E., Stark, H., Aldener, M., Vozella, M., Whitlow, S., Williams, E. J., Lerner, B. M., Jakoubek, R., Middlebrook, A. M., DeGouw, J. A., Warneke, C., Goldan, P. D., Kuster, W. C., Angevine, W. M., Sueper, D. T., Quinn, P. K., Bates, T. S., Meagher, J. F., Fehsenfeld, F. C., and Ravishankara, A. R.: Nighttime removal of $\mathrm{NO}_{\mathrm{x}}$ in the summer marine boundary layer, Geophys. Res. Lett., 31, L07108, doi:10.1029/2004GL019412, 2004

Carslaw, N., Carpenter, L. J., Plane, J. M. C., Allan, B. J., Burgess, R. A., Clemitshaw, K. C., Coe, H., and Penkett, S. A.: Simultaneous observations of nitrate and peroxy radicals in the marine boundary layer, J. Geophys. Res., 102, 18 917-18 933, 1997.

Carslaw, N., Creasey, D. J., Heard, D. E., Lewis, A. C., McQuaid, J. B., Pilling, M. J., Monks, P. S., Bandy, B. J., and Penkett, S. A.: Modeling $\mathrm{OH}, \mathrm{HO}_{2}$, and $\mathrm{RO}_{2}$ radicals in the marine boundary layer - 1. Model construction and comparison with field measurements, J. Geophys. Res., 104, 30 241-30 255, 1999.

Derwent, R. G., Jenkin, M. E., and Saunders, S. M.: Photochemical ozone creation potentials for a large number of reactive hydrocarbons under European conditions, Atmos. Environ., 30, 181-199, 1996.

Fleming, Z. L., Monks, P. S., Rickard, A. R., Heard, D. E., Bloss, W. J., Seakins, P. W., Still, T. J., Sommariva, R., Pilling, M. J., Morgan, R., Green, T. J., Brough, N., Mills, G. P., Penkett, S. A., Lewis, A. C., Lee, J. D., Saiz-Lopez, A., and Plane, J. M. C.: Peroxy radical chemistry and the control of ozone photochemistry at Mace Head, Ireland during the summer of 2002, Atmos. Chem. Phys., 6, 2193-2214, 2006,

http://www.atmos-chem-phys.net/6/2193/2006/.

Gratpanche, F., Ivanov, A., Devolder, P., Gershenzon, Y., and Sawerysyn, J.-P.: Uptake coefficients of $\mathrm{OH}$ and $\mathrm{HO}_{2}$ radicals on material surfaces of atmospheric interest, in 14th International Symposium on Gas Kinetics, Leeds, 1996.

Heard, D. E., Read, K. A., Methven, J., Al-Haider, S., Bloss, W. J., Johnson, G. P., Pilling, M. J., Seakins, P. W., Smith, S. C., Sommariva, R., Stanton, J. C., Ingham, T. S., Brooks, B., Leeuw, G. D., Jackson, A. V., McQuaid, J. B., Morgan, R., Smith, M. H., Carpenter, L. J., Carslaw, N., Hamilton, J., Hopkins, J. R., Lee, J. D., Lewis, A. C., Purvis, R. M., Wevill, D. J., Brough, N., Green, T., Mills, G., Penkett, S., Plane, J. M. C., Saiz-Lopez, A., Worton, D., Monks, P. S., Fleming, Z., Rickard, A., Alfarra, M., Allan, J. D., Bower, K., Coe, H., Cubison, M., Flynn, M., McFiggans, G., Gallagher, M., Norton, E. G., O’Dowd, C. D., Shillito, J., Topping, D., Vaughan, G., Williams, P., Bitter, M., Ball, S. M., Jones, R. L., Povey, I. M., ODoherty, S., Simmonds, P. G., Allen, A., Kinnersley, R., Beddows, D., DallOsto, M., Harrison, R. M., Donovan, R., Heal, M., Jennings, G., Noone, C., and Spain, G.: The North Atlantic Marine Boundary Layer Experiment (NAMBLEX). Overview of the campaign held at Mace Head, Ireland in summer 2002, Atmos. Chem. Phys., 6, 2241-2272, 2006 , http://www.atmos-chem-phys.net/6/2241/2006/.

Kanaya, Y., Sadanaga, Y., Matsumoto, J., Sharma, U. K., Hirokawa, J., Kajii, Y., and Akimoto, H.: Nighttime observation of the $\mathrm{HO}_{2}$ radical by an LIF instrument at Oki Island, Japan, and its possible origins, Geophys. Res. Lett., 26, 2179-2182, 1999.

Kanaya, Y., Matsumoto, J., Kato, S., and Akimoto, H.: Behavior of $\mathrm{OH}$ and $\mathrm{HO}_{2}$ radicals during the observations at a remote island of Okinawa (ORION99) field campaign - 2. Comparison between observations and calculations, J. Geophys. Res., 106, 24209 24223, 2001.

Kanaya, Y., Nakamura, K., Kato, S., Matsumoto, J., Tanimoto, H., and Akimoto, $\mathrm{H}$.: Nighttime variations in $\mathrm{HO}_{2}$ radical mixing ratios at Rishiri Island with elevated monoterpene mixing ratios, Atmos. Environ., 36, 4929-4940, 2002.

Lewis, A. C., Hopkins, J. R., Carpenter, L. J., Stanton, J., Read, K. A., and Pilling, M. J.: Sources and sinks of acetone, methanol, and acetaldehyde in North Atlantic air, Atmos. Chem. Phys., 5, 1963-1974, 2005,

http://www.atmos-chem-phys.net/5/1963/2005/.

Monks, P. S., Carpenter, L. J., Penkett, S. A., and Ayers, G. P. Night-time peroxy radical chemistry in the remote marine boundary layer over the Southern Ocean, Geophys. Res. Lett., 23, 535538, 1996.

Morgan, R. B. and Jackson, A. V.: Measurements of gas-phase hydrogen peroxide and methyl hydroperoxide in the coastal environment during the PARFORCE project, J. Geophys. Res., 107, 2002.

Norton, E. G., Vaughan, G., Methven, J., Coe, H., Brooks, B., Gallagher, M., and Longley, I.: Boundary layer structure and decoupling from synoptic scale flow during NAMBLEX, Atmos. Chem. Phys., 6, 433-445, 2006, http://www.atmos-chem-phys.net/6/433/2006/.

Purvis, R. M., McQuaid, J. B., Lewis, A. C., Hopkins, J. R., and Simmonds, P.: Horizontal and vertical profiles of ozone, carbon monoxide, non-methane hydrocarbons and dimethyl sulphide near the Mace Head observatory, Ireland, Atmos. Chem. Phys. Discuss., 5, 12 505-12 530, 2005.

Regina, K., Nykanen, H., Maljanen, M., Silvola, J., and Martikainen, P. J.: Emissions of $\mathrm{N}_{2} \mathrm{O}$ and $\mathrm{NO}$ and net nitrogen mineralization in a boreal forested peatland treated with different nitrogen compounds, Can. J. For. Res., 28, 132-140, 1998.

Saiz-Lopez, A., Shillito, J. A., Coe, H., and Plane, J. M. C.: Measurements and modelling of $\mathrm{I}_{2}, \mathrm{IO}, \mathrm{OIO}, \mathrm{BrO}$ and $\mathrm{NO}_{3}$ in the mid-latitude marine boundary layer, Atmos. Chem. Phys., 6, 1513-1528, 2006, http://www.atmos-chem-phys.net/6/1513/2006/.

Salisbury, G., Rickard, A. R., Monks, P. S., Allan, B. J., Bauguitte, S., Penkett, S. A., Carslaw, N., Lewis, A. C., Creasey, D. J., Heard, D. E., Jacobs, P. J., and Lee, J. D.: Production of peroxy radicals at night via reactions of ozone and the nitrate radical in the marine boundary layer, J. Geophys. Res., 106, 12669 $12687,2001$.

Smith, S. C., Lee, J. D., Bloss, W. J., Johnson, G. P., Ingham, T., and Heard, D. E.: Concentrations of $\mathrm{OH}$ and $\mathrm{HO}_{2}$ radicals during NAMBLEX: measurements and steady-state analysis, Atmos. Chem. Phys., 6, 1435-1453, 2006, http://www.atmos-chem-phys.net/6/1435/2006/.

Sommariva, R., Haggerstone, A.-L., Carpenter, L. J., Carslaw, N., Creasey, D. J., Heard, D. E., Lee, J. D., Lewis, A. C., Pilling, M. J., and Zádor, J.: $\mathrm{OH}$ and $\mathrm{HO}_{2}$ chemistry in clean marine air during SOAPEX-2, Atmos. Chem. Phys., 4, 839-856, 2004, http://www.atmos-chem-phys.net/4/839/2004/.

Sommariva, R., Bloss, W. J., Brough, N., Carslaw, N., Flynn, M., Haggerstone, A.-L., Heard, D. E., Hopkins, J. R., Lee, J. D., Lewis, A., McFiggans, G., Monks, P. S., Penkett, S. A., Pilling, M. J., Plane, J. M. C., Read, K. A., Saiz-Lopez, A., Rickard, 
A. R., and Williams, P. I.: $\mathrm{OH}$ and $\mathrm{HO}_{2}$ chemistry during NAMBLEX: roles of oxygenates, halogen oxides and heterogeneous uptake, Atmos. Chem. Phys., 6, 1135-1153, 2006, http://www.atmos-chem-phys.net/6/1135/2006/.

Still, T. J., Al-Haider, S., Seakins, P. W., Sommariva, R., Stanton, J. C., Mills, G., and Penkett, S. A.: Ambient formaldehyde measurements made at a remote marine boundary layer site during the NAMBLEX campaign - a comparison of data from chromatographic and modified Hantzsch techniques, Atmos. Chem. Phys., 6, 2711-2726, 2006,

http://www.atmos-chem-phys.net/6/2711/2006/.
Vrekoussis, M., Kanakidou, M., Mihalopoulos, N., Crutzen, P. J., Lelieveld, J., Berresheim, D. P. H., and Baboukas, E.: Role of the $\mathrm{NO}_{3}$ radicals in oxidation processes in the eastern Mediterranean troposphere during the MINOS campaign, Atmos. Chem. Phys., 4, 169-182, 2004, http://www.atmos-chem-phys.net/4/169/2004/.

Williams, E. J. and Fehsenfeld, F. C.: Measurements of soil nitrogen oxide emissions at three North American sites, J. Geophys. Res., 96, 1033-1042, 1991.

Williams, E. J., Guenther, A., and Fehsenfeld, F. C.: An inventory of nitric oxide emissions from soils in the United States, J. Geophys. Res., 97, 7511-7519, 1992. 